
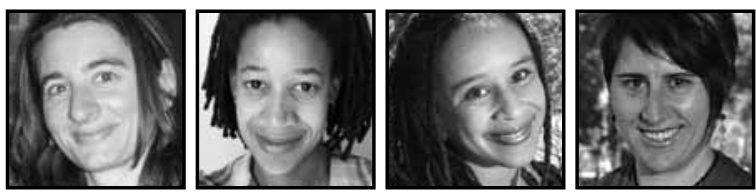

\title{
Digital Media Meets Informal Learning: Opportunities for Generating New Participatory Roles
}

\author{
Kathryn Hayes, Angela Booker, Beth Rose Middleton, \\ \& jesikah maria ross, UC Davis
}

\section{ABSTRACT}

This paper explores the rich learning that happens between defined learning spaces, such as that between formal curriculum and informal projects. Here we apply the notion of "hybrid space," to understand how such in-between learning spaces can facilitate a shift in participatory roles for college students engaged in a community media project. This study also highlights the ways in which media as a production medium can further transform the learning experience.

$\mathrm{n}$ both formal and informal education, learners are faced with the task of transforming the unknown into a something which can be incorporated into existing knowledge-a process which can be greatly facilitated by learner social and experiential participation (Flavell, 1996; Scribner, 1984; Rogoff et al., 2003; Lave \& Wenger, 1991). We argue that intersections between formal and informal educational contexts present unique opportunities for learners to participate meaningfully in their education, make personally significant contributions, and, in turn, gain access to future learning. Here, an intentional link has been developed between a formal learning environment, a university course, and community engagement where careful course design opens to the informal learning environment (Banks et al., 2007). In such intersections, digital media can act as a resource for a participatory process of investigation, reflection, analysis, and communication. Evidence from a study of college students' participation in a community media project provides an example of 
the ways learners are using media to redesign their participatory roles in the learning process. The project, called Restore/Restory, ${ }_{1}^{1}$ uses audio story gathering and editing to address cultural histories and community-based experiences, and, in the process, helps students make the journey from school-based learning to community engagement and contribution.

We will describe a framework for understanding transitions from school learning to community participation, discussing the ways digital media anchors the experience. In order to understand the perspectives learners gained in this boundarycrossing practice, we use the notion of "hybrid space" - where learning is rooted in multiple contexts and facilitated by social engagement across those contexts. We then provide evidence from the Restore/Restory project to illustrate students'journeys and realizations.

\section{Intersections as Opportunities Based in Hybridity}

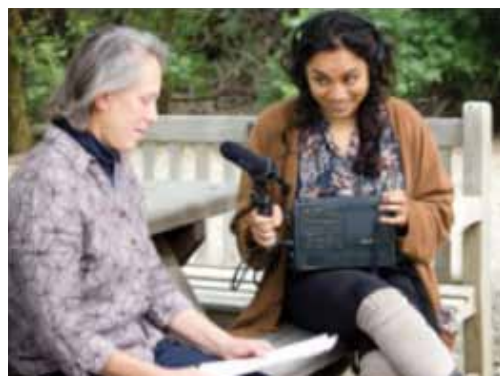

Much of the work of young people is in establishing space to participate and develop in a rapidly changing society (Erickson, 1968). Inside formal learning environments it has been difficult to support learners in this process at a systemic level, in part because the process requires facilitating social engagement beyond the classroom. At the college level, pathways toward increas-

ing participation beyond the classroom include capstone courses, service learning, participatory research, and internships, all of which provide support for social and skill-based aspects for learning (Baxter Magolda, 1994; Hettich, 2000; Rogers, Morrell, \& Enyedy, 2007).

In an effort to understand and support the learning which happens at intersections of formal schooling, community, and other environments, theorists have proposed an examination of a hybrid or "third space" (Gutierrez \& Rogoff, 2003; Engeström, 1993). Gutierrez (2008) described hybrid space as "a transformative space where the potential for an expanded form of learning and the development of new knowledge are heightened" (p. 152). These spaces emerge from social engagement facilitated by cross-contextual learning environments (Gutierrez, 2008; Yamazumi, 2009; Calabrese Barton, Tan, \& Rivet, 2008). Moje et al. (2004) contend that hybrid spaces allow learners to generate new knowledge and new participatory identities. In this regard, hybrid 
spaces can effectively reposition learners in new societal roles and even break down barriers that restrict access to societal participation (Engeström, 1991).

Restore/Restory, a project where students used a growing historical knowledge base and the tools of digital media to engage with a specific geographic community, provides an opportunity to examine the hybrid spaces generated and sustained through students' investigations into community members' place-based work. The project illustrates practices that make learning trajectories visible and accessible to learners in which digital media tools make it possible to integrate what has been learned in classrooms with what can be practiced in external environments. Moreover, the moment of return, when collected digital media and new skills are presented back to both the academic and external community, becomes a salient moment for both students and community members in defining the learning which occurred.

\section{Learning as a Journey With a Moment of Return}

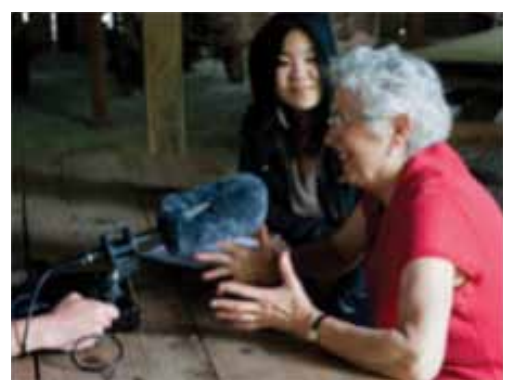

Concepts derived from early anthropological work on Rites of Passage (Van Gennep, 1961) can be applied here as a useful metaphor for understanding the relationship between the physical process of going out and procuring media and the transformation of knowledge reported by students. According to this framework, initiates must separate from their social context and go on journey to a transitional place in which they undergo some sort of transformation (Watson-Gegeo \& Gegeo, 2011; Wallace, 1966). They then return to their prior social context with a new identity, in some cases transforming the collectively held knowledge of the social group. The cycle highlights a journey from what is known, across a threshold that marks the beginning of a transformation that will result from grappling with what is unknown, and a return to share what has been learned. Youth media work can facilitate such a return to the community, in which the learner becomes a "master of two worlds" and can engage in boundary crossing between multiple participatory identities.

Evidence indicates that a critical experience for Restore/Restory participants was the return to the initial social context or community to which students were responsible, within their digital media production process. Many students reported the skills, knowledge, and relationships they gained opened new pathways toward future careers and other opportunities for learning. Thus the learning process can be 
defined as a set of opportunities to begin the journey anew and take on increasingly complex levels of responsibility in the process. Such programs may facilitate a spiral toward increasing access to the rights of participation (Lave \& Wenger, 1991; Rogoff et al., 2003), within which the use of digital media gives students a tangible resource for taking on new roles and participation structures.

\section{Methods}

Data for this study was collected during the first year of a two-year project, Restore/Restory. The project is a collaboration between a university outreach program $^{2}$ and the Preserve Conservancy, with the purpose of creating a multi-media public history of the site, including a site-based audio tour and interactive website. The project design involved many students, faculty, staff, and community members, creating an opportunity for college students to participate in a hybrid learning environment which spanned college courses and community involvement. Fifteen students in a seminar course titled "Community Media" participated for two quarters, examining theory and practice of public history, learning fundamentals of community media production, and recording and editing audio interviews focused on the natural and human history of the Preserve. An additional 46 Intensive Writing course students participated for one quarter, transcribing the interviews and creating written storyteller profiles. Independent studies course students created photo essays, and three graduate students were involved in a variety of organizational, production, and research activities. Community members working on the project included eleven on the advisory group (five of which were Conservancy staff and board members), and 48 storytellers who participated in project recordings.

Findings are derived from field notes from observational data collected across all project phases, including planning meetings, advisory group meetings, class sessions, and story collection days, totaling 35 hours. In addition, student participants filled out pre- and post-surveys and wrote reflective essays. Class debriefs and the final showcase were recorded and transcribed, along with interviews of the instructor and one student. Artifacts of student work include edited audio stories, transcribed and written storyteller profiles, and photo-journalist work.

Coding followed a grounded theory model based on the work of Glaser and Strauss (1967), which revealed both the importance of media to student learning and the salience of the moment of return - the latter encapsulated in a showcase of student work. Findings presented in this paper include types of learning which occurred in hybrid space as revealed through the process of "the journey"-going out and 
collecting stories; and "the return"-presenting their collected, edited, and polished stories for the community.

\section{Media as a Doorway to Hybrid Space}

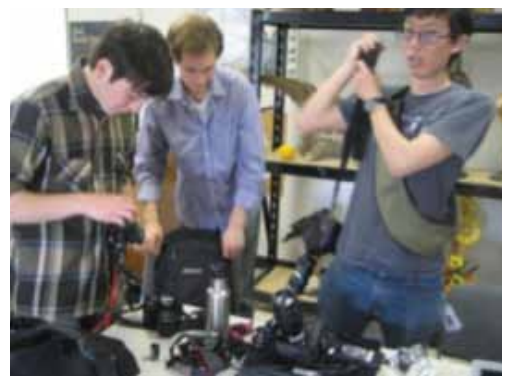

Engaging in digital media production provided students a means to access community members and community experience within a particular role. These roles (as journalist, historian, recording artist, etc.) gave students experiences and status which may not have been available to them in their previous role solely as "student" (Goldman, Booker, \& McDermott, 2008; Soep, 2003). The use of digital media facilitated students' development along multiple pathways that included technical, pragmatic, and political practice (Booker, 2010). The combination of the technical aspects of the task, engaging with real people around politically complex concepts and viewpoints, and crafting a final product from the raw footage were anchored in the media practices as much as the community engagement.

In the Community Media Seminar, students were intimately involved in the project. After training with the project director on audio equipment and interview techniques, they were responsible for recording stories out at the Preserve (during five "Community Story Days"), documenting storyteller information, interviewing storytellers, and editing the final narratives to become part of a public website. They developed expertise, advising one another about microphone placement, background noise, and interview technique. By the fifth story collection day, they were confident and enthusiastic interviewers.

Students in the Community Media course experienced a significant role shift as they moved from students to teachers of media, a process which was corroborated through several sources of data (interviews, observations, and surveys). Instructor jesikah maria ross describes how she taught technology skills within the course:

I followed a process by which I would teach someone, and they would teach another person... I teach Amber, and Amber's now going to teach Dane, and then Dane teaches Amy and I ask Amber to back him up. Usually the students pick up on what's being conveyed, or what's not being done properly, [such as] mike placement, 45 degree angle...

- jesikah maria ross, Community Media Seminar instructor 
In surveys, almost all students reported learning skills from peers. During an interview, one student described how the becoming a teacher in this process allowed a metacognitive reflection of her own learning.

So I was teaching [the new students] to use this equipment, which is very expensive and very advanced... And it showed me how much I've learned in this whole process, being able to teach people not only how to run audio equipment, how to mike people professionally, but also the skills that go into interviewing a person and really getting onto their level without overshadowing what it is that they're there to share with you.

- Amber, Community Media Seminar student

Her statement indicates an increasing sophistication in her understanding of both the technical equipment and the primary responsibility to represent a point of view with integrity. As student teams conducted interviews during Community Story Days, the geographical space of the Preserve became the site of hybrid space, a space of multiple contexts - community, physical, academic - characterized by social engagement. In this hybrid space students engaged in teaching and learning of both technical media skills and social/interview skills. For example, at the beginning of the first story recording on one particular Community Story Day, John explained the layout of the Preserve to a few students new to the course, including where they could take storytellers for the best interview sites. Often students asked one another which role they should take (note taking, recording, etc.) and how to perform those roles. Once the story recording process got underway, students advised one another on how to proceed. For example, on one of the student teams, a student noticed the wind was too loud, creating interference with the sound. The other student suggested they use another angle, and demonstrated the new layout with her pencil. The recording student agreed, moved to the other side, and the two resumed the interview.

In addition, the specific roles facilitated by the use of digital media, and the skill sets needed for these roles, provided students a context within which to engage with community members with some level of expertise. During the observed story recording sessions, students in the Community Media course clearly took a leadership role in guiding the storyteller to an interview spot, as well as directing others amongst their team. They confidently explained the interview process to community members, and stopped the interview if necessary due to an external noise. They even occasionally corrected or made suggestions to the director, jesikah. For example, as storytellers were arriving, Amber suggested that jesikah create a place to keep their permission slips, thereby contributing to the organization of the process. 
During the final Community Story Day we observed an additional 20 instances in which students took charge, remembered something, or advised jesikah.

Several comments corroborate and further explain the sense of student expertise. Dan Swale, a lecturer involved in the project who was observing during Community Story Day, was discussing student interview work when he mentioned, "They are co-initiators of the project...they make people feel so comfortable." Upon returning from an interview, a community member said, "this group is very professional."

Student comments from interviews and surveys, along with Dan Swale's comments above, speak to the shift from a participatory role of "student," learning about public history in a seminar class, to a different and more expanded set of participatory roles. These roles included those of media expert, journalist, contributor to a valued community project, and even project "co-initiators." These role transitions would have been difficult without a hybrid space between the formal learning environment of the university and the informal space of community interaction. This hybrid space in some ways facilitated stepping up to another level of participation.

Enhanced participation was also made possible through the use of digital media. It is reasonable to anticipate that students could conduct an interview without a recorder or other equipment, so the role of digital media was not simply to capture the interview. Rather, media production served as the impetus for students to play the role of a journalist or recording artist. As they researched the issues at the Preserve and raised questions, and as they developed a narrative about their subjects, they looked for opportunities to capture compelling stories. In addition, participants spent a great deal of time with their recordings, editing their pieces down in length and made difficult choices about what to include. The process of investigation, narrative development, and editing allowed them to use media products to hold open the hybrid space (in terms of the intersection of multiple contexts), in which their access to community events and processes of conflict resolution were kept alive through ongoing work with the footage.

In an interview, one student elaborated on the role media played in facilitating access to experience and understanding of the Preserve stories:

The role of technology in implementation of story gathering was integral in the sense that it was the vessel through which we were collecting and harvesting the information...From there the technology was integral 
because we went beyond the audio equipment and we took this digital version of the story and we integrated it into the final cut pro system and from there we were able to chop it up, spread it out, slow it down, piece things together...

- Amber, Community Media Seminar student

In participating in this project, students engaged in creative production of knowledge, in the form of edited audio/photo stories. These productive works extend beyond typical written school work in that they will be publicly displayed on a website. However, and perhaps even more importantly, there is a certain currency to digital works. Students were engaged in work more similar to the media integration in their everyday lives than normal school work, but beyond simple lay use of video or pictures, they learned, used, and taught with professional tools of the trade. Amber's use of the word "vessel" illustrates how media literally contained the experience of gathering and working with information-an experience within which they not only engaged in new participatory roles, but also encountered and integrated new knowledge.

\section{Transformation of Knowledge}

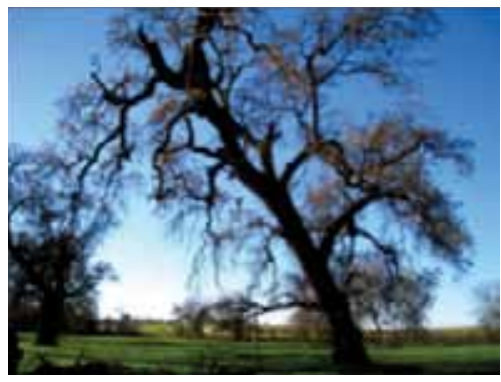

On the most basic level, the collection of stories through audio and visual media also created a context where students were able to explore a physical space (the Preserve) as well as an overlapping experiential space (community connection to and interaction with the Preserve). This then facilitated reflection on both how people negotiate contested spaces, and students' own relationships with place and community.

This contextualized learning process, facilitated by media production, provided a particular space for students to encounter and interrogate knowledge and experience. For example, the Community Media students reported that the process of recording and editing stories shifted their thinking. For many of them, it broadened their understandings of place and of how humans might interact with place, including whether people can live and grow up somewhere ecologically preserved, how an ecological preserve can be valued by a community, and how human relationships can impact the land in long-term ways. For Derric, an ecology major in the Community 
Media Seminar, participation in the project increased his understanding of restoration as a complex and ongoing process without a perfect outcome. He described what he learned in this way: "The reiteration of the idea of restoration not being static, or about freezing time in a museum-like experience. Restoration is not really discrete, but rather a process."

Much of this more subtle learning arose out of engagement with the conflict around the land preservation process. Although the Conservancy's mission involves restoration, it was partially established by Terra Mining Company, and a few members of the board are connected in some way to mining. Aspects of community conflict around mining and environmentalism came to light in the initial meetings, exemplified by delicate negotiations and hinted-at issues. For example, several people expressed misgivings at known environmental activists being invited to join the advisory group. However, it was unknown whether students would encounter this "multiplicity" of community, and if so, how they would interpret or learn from the conflicts. Through analysis of transcribed meetings, interviews, and notes, evidence emerged that conflicts and multiple points of view within the community actually served as key aspects of the students' learning process.

For example, Jamie's comment about understanding the perspective of the miners provides an example of contextualized thinking which can be interpreted in multiple ways.

I loved the stories that brought to light the kindness of the miners, I think often miners and the industry are vilified and it was great to hear their stories and hear environmentalists credit them for the work they had done. It definitely changed my perspective.

This comment is illustrative of complex learning for several reasons; first, it is likely that, in the university setting, environmentalist viewpoints have greater credence than miner viewpoints, and this exposure to miner viewpoints helped a student develop greater compassion for and understanding of different points of view. It is possible that Jamie has a somewhat simplified view of the conflict due to not having all of the data at hand; nonetheless her viewpoint grew and encompassed more of human experience in relation to the land than it had when she was simply attending classes at the university.

Another example of students grappling with and learning from the community conflict comes from the debrief of the winter quarter Community Media course. 
Dane discussed three storytellers he worked with, two from the mining industry (Brad and Russell) and one environmental activist (Ken).

For us we had three really perfect people, because each came from a really different background. We had Brad who was this miner who had been involved in this place... who had a really deep connection to the land, and then we had Russell who was this really funny, witty guy, this representative of Terra-he came from more of a mining background, that mindset. And he still had a deep connection with the earth. And then we had Ken, who was Mr. political activist, you know, down with Terra, you know, I had to fight all of these people off and so, I thought that the synthesis of those three stories...was just a great combination.

- Dane, Community Media Seminar student

Although the storytelling itself is a political process, in this case (due to the distribution of story collection, transcription, and editing) it allowed students access to multiple stories that provided insight into experiences different than their own. This is reflected in realizations such as "not all mining companies are bad." The Conservancy community had engaged in a challenging negotiation, resulting in a collaborative process in which land was moved out of gravel production and into a form of restoration. In the process of working on this project, students became familiar with storytellers' complex and sometimes conflicting relationships to the land and to one another. Students engaged in a questioning process regarding the value of restoration, the environmental commitments of miners, and the possibilities of collaboration.

The examples above, pulled from student surveys and interviews, illustrate the "transformation of knowledge" which happens as students move out of familiar space and into a new space characterized by social engagement across normally immutable boundaries (university and community), facilitated by media-making. However, what made the experience salient for students was the real-world context of the work-their responsibility to people beyond their teachers or themselves.

\section{The Return}

Once students engaged in the process of collecting data, creating stories, or shaping a media piece based on their experience, they returned to present their pieces to their community. This return included both a showcase of student work attended by community members, advisory group members, other students, and instructors; as well as the website in which student work was publicly displayed. 


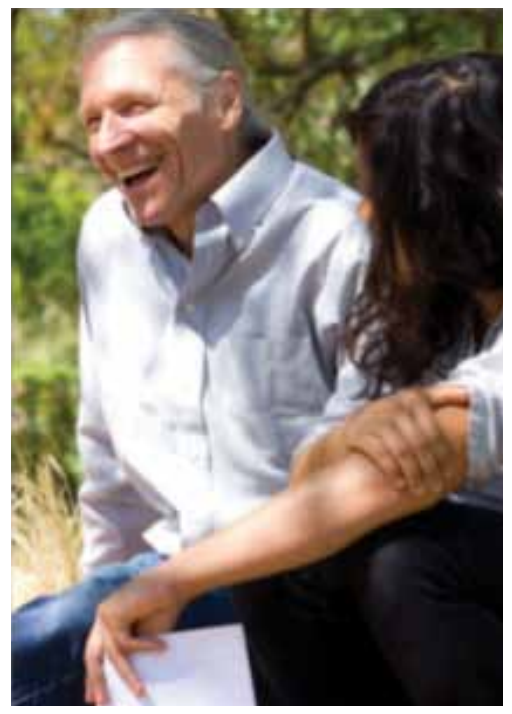

At the showcase, students from all courses presented their work. This work included two-minute, edited audio public history stories, photo essays, and written profiles generated from community member interviews. Community members reviewed the work, providing context and realistic feedback. Students also had an opportunity to examine the work of other students across courses and disciplines.

In final reflections, when asked to discuss what it was like for them to think about their writing appearing in a public context, many students noted the importance of the "real" nature of the product to their experiences as writers. Angel, a Writing Intensive student, wrote, "When a person's work is put up for the public to see, it inspires the worker to do the best they can do." As another student, Rommel, wrote:

I wasn't just writing for a grade, I was writing for a real "thing" ...A new level of meaning was placed on my work. I knew that other people would be seeing it, reading it, judging it - forever. The transcript and the profile are public record and if that doesn't make you think twice about how you write your paper or the respect and time that you put into writing it, then I don't know what will!

Several also wrote that the contextualized nature of the project gave their work a sense of worth. As Rommel continued, "It kind of made the work I put into my writing worthwhile... more than just a professor or a TA would be seeing my work, so I guess I put a bit more pride into my work." According to another student, "The profile I had written really did something... I had given the place a face. I had affected its reputation, thus affecting it."

In addition to inspiring pride and a sense of worth, the hybrid space created by the intersection of student work and community feedback allowed for new ways of engaging with the act of writing, compiling, and editing, fostering a more complex set of skills. In a written response, Phuong, a Writing Intensive student, noted specific writing improvements which had not occurred to him before community viewing. "As people stood and viewed my work, I began to think of the improvements such as 
what was the best length and format for the profiles." Others noted the political savvy involved in creating a profile for public consumption: "I wanted to write his profile in a way that respected his side of the story and to give the community members a look into Ken's motives at the time."The process of representing community members was fraught with difficult decision making, knowing they would see the end result.

In addition, students wrote of how they realized through the showcase process how their work fit into a larger project.

The campus event was extremely beneficial for me because...I was able to make a connection between our work and the whole project. It was great to meet and get to know all the people involved with the project. Seeing the passion and dedication to the project definitely made me more excited and honored to be a part of it all.

- Sara, Writing Intensive Course student

Interaction across diverse groups of students in the showcase provided additional opportunities for learning through juxtaposition of experience. In surveys, students mentioned their excitement in sharing with peers:

When I heard the audio profile I was very impressed that they could mold the words they heard so effectively... as to keep the personality of the individual they had based their profile on while ensuring that the words they said were clear and understandable. This is what kind of editing I had attempted to do on my profile, but now I realize I should have further edited her sentences.

- Tanner, Writing Intensive Course student

Tanner's comment implies a transformation of how skills are learned when multiple groups of students engage in various types of media production with the ultimate goal of public consumption.

Not all of the dialogic encounters between students' work and community feedback were positive; community members did not hold back in critiquing both student grammar and choice of topics, and aspects students had little control over, such as the spelling of names they had only heard. Nonetheless, the new layers of meaning derived from interaction with the community and other students in the moments of return lent gravity and complexity to student encounters with the material. 
An oft-cited feature of experiential or project-based courses such as this one is student motivation and buy-in (e.g., Blumenfeld et al., 1991). As the learning experience moves closer to a real-world context, students consider the relevance to their lives, and the space of learning comes closer to bridging the personal lives of students with school spaces (Moll et al., 1992). Several student comments indicated an attitude that this was more than an assignment. Students voluntarily pored over interview questions, asked for advice, and introduced themselves to community members. In a sense, the interaction with community members reinforced the reality of the workthis was not a performance or a presentation in a class. On one hand, there were real social consequences to "messing up;" on the other hand, there was joy to be derived from a community member who reacted well to the students' work.

In addition, students voluntarily reported on the significance of the project in achieving their career and educational goals. Here the transition to a new participatory role is most apparent. According to the survey responses of one Writing Intensive student: "I am an environmental science [major, so this project] was pertinent to my future and the work that I may be involved in... I gained some more understanding of what people in the environmental field can do for a job." For this student the encounter with new forms of knowledge led to new potential forms of participation. In her interview, Amber spoke extensively on the value of the project for her college experience and her future career:

I feel like this project has been integral to my entire college career, which is ironic given that it has only flourished in the last two quarters. ... I never encountered a scholastic opportunity in which I had the ability to literally produce something, to come out of the end of the quarter with a living breathing project with a life of its own. So, for me, I see this project... as being the keystone to my college career... I have it on my resume for sure. - Amber, Community Media Studies Seminar student

For the college students, the return was integrally rooted in the responses by the community and the relationship to their futures outside of the school environment. For some, the return thus poised them for a new journey, as van Gennep suggests occurs in a rite of passage (Watson-Gegeo \& Gegeo, 2011; Wallace, 1966), with a different or more detailed vision of their future as new roles were opened to them. 


\section{Discussion}

In this paper, we have described the different ways learning new participatory roles can be supported through hybrid spaces between formal and informal learning environments (Gutierrez, 2008). Student comments and reflections show the importance of the way media created alternate opportunities for engagement and for new roles, as well as the importance of the public nature of the project in their motivation and learning. Conflict was productive for learning in this context, in part because the learners were responsible for characterizing the conflicts and examining the validity of varied viewpoints. The use of digital media was not simply motivating but served as an anchor for generating artifacts and acting on those artifacts to develop both knowledge and for applying that knowledge. Van Gennep's Rites of Passage provide a metaphor for understanding how such a return can be so powerful as learners transition into a new form of participation incorporating new knowledge. The return to position of learner is complemented by both new skills and a recognition of the new types of opportunities (jobs, careers) that await.

A discussion of transition and return begs the question as to how the return has transformed the school community. We have discussed above how students themselves encounter new knowledge and transform existing knowledge, incorporating it into their understanding and cycling into the next stage of their own journey, but how does this knowledge then transform the original learning context? Are schools transformed at any level of practice?

Restore/Restory students commented on the importance of the project in their schooling experience. Some focused on how their university education should include such an applied project, which, in Jamie's words, "added purpose" to the educational experience. Moreover, this project ended in a product, audio and written stories for the website, which were valuable, "fruitful," or "amazing." Along these lines, several students felt that there should be more projects like this established between universities and communities.

Such projects highlight an opportunity, but also serve as an example of issues of implementation. When asked about challenges which arose during the process, students most often mentioned time constraints imposed by the fast pace of the quarter system and their other coursework. Regarding this, several students indicated an important systemic issue-this course was offered pass/no pass and not required for their major. Even though many of them felt it was the most important class of their year, if not their college career, they were forced to prioritize their graded and required coursework. If such a course was worked into their major as a requirement it 
would help ameliorate the tension expressed by students about a project which they felt was literally a "culmination" of all they were doing at the university, yet one which was underemphasized in major requirements.

Schools at both the k-12 and university level may benefit from incorporating such projects, especially if committed to learning which bridges school, home, and community contexts. The opportunities generated by the use of media and the boundary crossing spaces within community/school projects may allow for shifts in participatory identity, providing students with tools to engage in the next stage of learning with agency and activism.

\section{Notes}

1. Real names are used as requested; in all other cases names have been substituted for confidentiality.

2. The project is led by the UC Davis Art of Regional Change, a university-community engagement initiative that brings students, scholars, and artists together with community groups to collaborate on media arts projects that strengthen communities, generate engaged scholarship, and inform regional decisionmaking.

\section{References}

Banks, J. A., Au, K. H., Ball, A. F., Bell, P., Gordon, E. W., Gutierrez, K. D., et al. (2007). Learning in and out of school in diverse environments: Life-long, life-wide, life-deep. The LIFE Center (The Learning in Informal and Formal Environments Center) and the Center for Multicultural Education, University of Washington, Seattle.

Baxter Magolda, M. B. (1994). Post-college experiences and epistemology. The Review of Higher Education, 18(1), 25-44.
Blumenfeld, P.C. Soloway, E., Marx, R., Krajcik, J., Guzdial, M., \& Palincsar, A. (1991). Motivating project-based learning: sustaining the doing, supporting the learning. Educational Psychologist, 26, 369-398.

Booker, A. (2010). Framing youth civic participation: Technical, pragmatic, and political learning. In L. Lin, H. Varenne, \& E. W. Gordon. (Eds.) Educating comprehensively: Varieties of educational experiences (209231). Lewiston, NY: Edwin Mellen Press. 
Calabrese Barton, A., Tan, E., \& Rivet, A. (2008). Creating hybrid spaces for engaging school science among urban middle school girls. American Educational Research Journal, 45(1), 68-103.

Engeström, Y. (1991). Non scolae sed vitae discimus: Toward overcoming the encapsulation of school learning. Learning and Instruction: An International Journal, 1, 243-259.

Engeström, Y. (1993). Developmental studies of work as a test bench of activity theory: Analyzing the work of general practitioners. In S. Chaiklin, \& J. Lave (Eds.), Understanding practice: Perspectives on activity and context. Cambridge: Cambridge University Press.

Erickson, E.H. (1968). Identity: Youth and crisis. New York: W.W. Norton \& Company.

Flavell, J. H. (1996). Piaget's legacy. Psychological Science, 7(4), 200-203.

Glaser, B., \& Strauss, A. (1967). The discovery of grounded theory. Chicago: Aldine.

Goldman, S., Booker, A., \& McDermott, M. (2008). Mixing the digital, social, and cultural: Learning, identity and agency in youth participation. In D. Buckingham. (Ed.) Youth, identity, and digital media (185-206). MacArthur Foundation Series on Digital Media and Learning. Retrieved May 22, 2012, from http:// mitpress.mit.edu/catalog/item/default. asp?ttype $=2 \&$ tid $=12594$

Gutierrez, K. D. (2008). Developing a sociocritical literacy in the third space. Reading Research Quarterly, 43(2), 148-164.

Gutierrez, K. D., \& Rogoff, B. (2003). Cultural ways of learning: Individual traits or repertoires of practice. Educational Researcher, 32(19), 19-25.

Hettich, P. (2000). Transition processes from college to career. Paper presented at the Annual Conference of the American Psychological Association. Washington DC.

Lave, J., \& Wenger, E. (1991). Situated learning: Legitimate peripheral participation. Cambridge: Cambridge University Press.
Moje, E. B., Ciechanowski, K. M., Kramer, K., Ellis, L., Carrillo, R., \& Collazo, T. (2004). Working toward third space in content area literacy: An examination of everyday funds of knowledge and discourse. Reading Research Quarterly, 39, 38-72.

Moll, L., Amanti, C., Neff, D., \& Gonzalez, N. (1992). Funds of knowledge for teaching, using a qualitative approach to connect homes and classrooms. Theory Into Practice, 31(2), 132-141.

Rogers, J., Morrell, E., \& Enyedy, N. (2007). Studying the struggle: Contexts for learning and identity development for urban youth. American Behavioral Scientist, 51(3), 419-443.

Rogoff, B., Paradise, R., Mejia Arauz, R., CorreaChavez, M., \& Angelillo, C. (2003). Firsthand learning through intent participation. Annual Review of Psychology, 54, 175-203.

Scribner, S. (1984). Studying working intelligence. In B. Rogoff \& J. Lave (Eds.), Everyday cognition: Development in social context (pp. 9-40). Cambridge: Harvard University Press.

Soep, E. (2003). Learning about research from youth media artists. Penn GSE Perspectives on Urban Education, 2(1), 1-6.

Van Gennep, A. (1961). The rites of passage (Les rites de passage). Chicago: University of Chicago Press. (Original work published 1909)

Wallace, A.F.C. (1966) Religion: An anthropological view. New York: Random House.

Watson-Gegeo, K., \& Gegeo, D. W. (2011). Divergent discourses: The epistemology of healing in American medical clinic and Kwara'ae village. Anthropology of Consciousness, 22(2), 209-233.

Yamazumi, K. (2009). Not from the inside alone but hybrid forms of activity: toward an expansion of school learning. Actio: An International Journal of Human Activity Theory, 2, 35-55. 


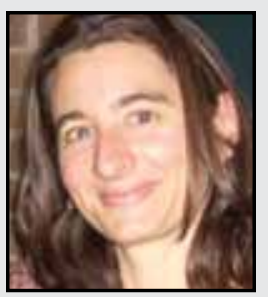

Kathryn Hayes is currently working on her PhD at UC Davis, where her research pertains to the twin foci of science education policy and place-based environmental education, with attention to the impacts of accountability regimes. Her experience in environmental education over ten years informs her teaching of environmental science and education courses at California State University, Sacramento, where she has been an adjunct faculty for the past six years.

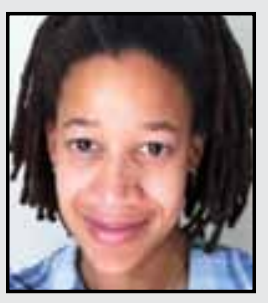

Angela Booker, PhD, is Assistant Professor in the School of Education at UC Davis. Her research interests include youth civic participation, family-based problem solving, and design thinking as a way to support learning. Booker is currently studying ways youth, families, and schools make use of media and technology for participation, learning, and community development. She earned her PhD from the Stanford University School of Education.

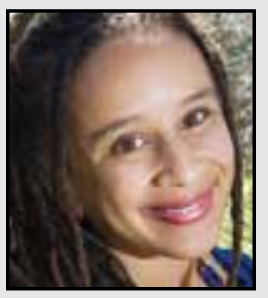

Beth Rose Middleton, PhD, is Assistant Professor of Native American Studies at UC Davis. Her research centers on Native American environmental policy. She has published on Native economic development in Economic Development Quarterly, on political ecology and healing in the Journal of Political Ecology, on mapping allotment lands in Ethnohistory, and her book on Native land trusts, Trust in the Land, was published in 2011 by University of Arizona Press.

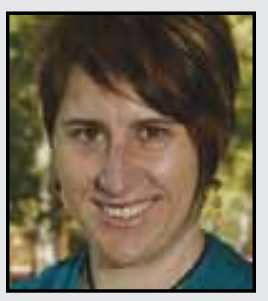

jesikah maria ross is an award-winning media artist and the founding director of the UC Davis Art of Regional Change, a program that brings scholars, students, and artists together with social action groups to collaborate on place-based storytelling projects that strengthen communities, generate public scholarship, and inform regional decision making.

LINK TO:

http://artofregionalchange.ucdavis.edu/ 